\title{
Questioning the puzzle: Fiscal policy, exchange rate and inflation
}

\section{Laurent Ferrara ${ }^{1}$, Luca Metelli ${ }^{2}$, Filippo Natoli $^{3}$ and Daniele Siena ${ }^{4}$}

\author{
January 2020, WP \#752
}

\begin{abstract}
The paper re-investigates the effects of government spending shocks on the real exchange rate and inflation. In contrast with some previous puzzling results, we find that an increase in government spending appreciates the real exchange rate and is inflationary; besides, it induces a trade balance deficit and a decrease in consumption. The discrepancy with the existing literature lies in the identification of fiscal shocks: embedding a narrative approach in a proxy-SVAR is what makes the difference. Empirical findings are then well explained by a standard estimated open real business cycle model
\end{abstract}

Keywords: Fiscal Shocks, Real Exchange Rate, Inflation, Proxy SVAR, Narrative Shocks JEL classification: E62, F41

\footnotetext{
${ }^{1}$ SKEMA Business School - University Côte d'Azur, laurent.ferrara@skema.edu

2 Banca d'Italia, luca.metelli@bancaditalia.it

${ }^{3}$ Banca d'Italia, filippo.natoli@bancaditalia.it

${ }^{4}$ Banque de France, daniele.siena@,banque-france.fr
} 


\section{NON-TECHNICAL SUMMARY}

\section{Impulse response functions from a one standard deviation shock on U.S. government spending on inflation and real exchange rate}
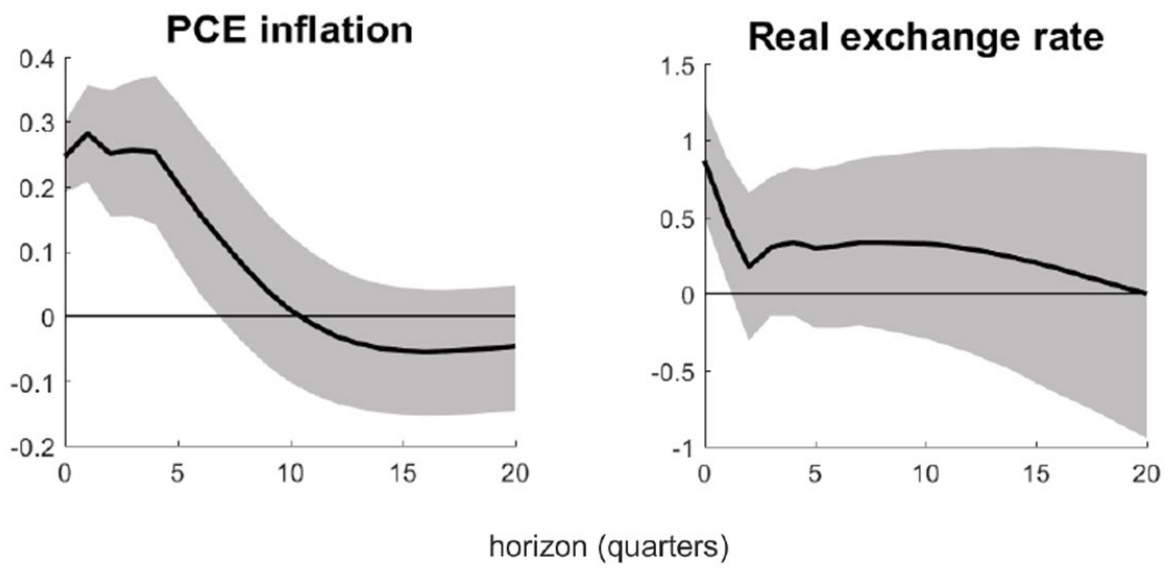

Impulse-responses estimated using a proxy-SVAR approach. Government spending is instrumented with the military narrative series of Ramey (2016). The real effective exchange rate is defined as the weighted basket of foreign goods to domestic goods: an increase stands for an appreciation. Shaded bands denote the $68 \%$ pointwise credible sets.

Since the Great Recession, the debate on the role of fiscal policy has gained traction, as discretionary fiscal measures have started afresh to serve as policy tools in advanced economies. The renewed interest in fiscal policy has spurred considerable academic research on its effects. However, despite the importance of the question, there is still no consensus on how inflation and the real exchange rate respond to fiscal shocks. The aim of this paper is to re-examine the implications of fiscal policy for domestic and international variables, starting from the responses of inflation and the real exchange rate.

According to standard theoretical frameworks, whether Real Business Cycle or old and newKeynesian theories, inflation should increase and the real exchange rate should appreciate in response to an increase in government spending. However, the empirical literature finds mixed results. On inflation, while Edelberg et al. (1999), Zeev and Pappa (2017) and Caldara and Kamps (2017) find that a government spending shock is inflationary, Fatás and Mihov (2001b), Canzoneri et al. (2002), Mountford and Uhlig (2009), Dupor and Li (2015), Ricco et al. (2016), Jorgensen and Ravn (2019) and D'Alessandro et al. (2019) find that the same shock decreases prices/inflation.

On the real exchange rate, Kim and Roubini (2008) found that fiscal expansions depreciate the real exchange rate. This result has then been confirmed by Monacelli and Perotti (2010), Enders, Muller and Scholl (2011), Ravn, Schmitt-Grohe and Uribe (2012) and Ilzetzki, Mendoza and Vegh (2013). However, Auerbach and Gorodnichenko (2016), show that unanticipated shocks to announced military spending cause an appreciation of the U.S. dollar. Moreover, Born et al. (2013), Kim (2015), Forni and Gambetti (2016), Born et al. (2019), Miyamoto, Nguyen and Sheremirov (2019), Boehm (2019) and Lambertini and Proebsting (2019) argue that the response of the exchange rate depends on country characteristics, like the stage of economic development, the exchange rate 
regime, the timing of the fiscal shock (namely if it is anticipated or not) and the sign or type of fiscal instruments (government consumption or investment).

This paper re-examines and merges the closed and open economy debate by employing a different identification scheme to estimate the impact of fiscal spending shocks on inflation and the real exchange rate. The military narrative series constructed by Ramey (2011) and Ramey (2016a), after having showed that is a valid instrument for unanticipated fiscal shocks, is used into a Vector AutoRegression, employing the proxy-SVAR methodology developed by Mertens and Ravn (2013) and Stock and Watson (2008). This model is estimated on quarterly United States data using a Bayesian approach over the 1964Q1-2015Q4 period. Using this identification technique, most puzzling results dissolve: government spending shocks are inflationary, appreciate the real exchange rate, worsen the trade balance and decrease private consumption. Multiple robustness checks are also included.

Finally, in order to check the theoretical coherence of our empirical estimates, we set up a standard two-good RBC open economy model and estimate it to match the impulse-responses to a government spending shock. This exercise enables to get an immediate feeling on how far we can go in explaining empirical results with a standard and frictionless framework. Empirical dynamics are aligned with standard theoretical predictions and the responses of an estimated real business cycle small open economy model match extremely well empirical impulse-responses.

The contribution of the paper can be seen as a reconciliation of empirical results with standard theories or, more simply, as an incitement to further research on the joint response of domestic and international prices to fiscal shocks.

\title{
Les Effets de la Politique Budgétaire sur le Taux De Change Réel et l'Inflation : une Remise en Question
}

\begin{abstract}
RÉSUMÉ
Dans ce travail, nous reconsidérons les effets d'un choc de dépenses publiques sur le taux de change réel et l'inflation. Contrairement à certains résultats surprenants obtenus par la littérature empirique récente, nous montrons qu'une hausse des dépenses publiques entraîne une appréciation du taux de change réel et des pressions inflationnistes, ainsi qu'un déficit de la balance commerciale et une baisse de la consommation. Les écarts entre nos résultats et ceux de la littérature récente sont liés à la méthode d'identification des chocs de dépenses publiques utilisée, à savoir une approche de type proxy-SVAR qui utilise comme variable instrumentale les dépenses militaires. Enfin, nous montrons que nos résultats empiriques sont en ligne avec ceux d'un modèle théorique standard en économie ouverte.
\end{abstract}

Mots-clés : choc de dépenses publiques, dépenses militaires, proxy-SVAR, taux de change réel, inflation

Les Documents de travail reflètent les idées personnelles de leurs auteurs et n'expriment pas nécessairement la position de la Banque de France. Ce document est disponible sur publications.banque-france.fr 


\section{Introduction}

Since the Great Recession, the debate on the role of fiscal policy has gained traction, as discretionary fiscal measures have started afresh to serve as policy tools in advanced economies. The renewed interest in fiscal policy has spurred considerable academic research on its effects. However, despite the importance of the question, there is still no consensus on how inflation and the real exchange rate respond to fiscal shocks. The aim of this paper is to re-examine the implications of fiscal policy for domestic and international variables, starting from the responses of inflation and the real exchange rate.

According to standard theoretical frameworks, whether Real Business Cycle or old and new-Keynesian theories, inflation should increase and the real exchange rate should appreciate in response to an increase in government spending. However, the empirical literature finds mixed results. On inflation, while Edelberg et al. (1999), Zeev and Pappa (2017) and Caldara and Kamps (2017) find that a government spending shock is inflationary, Fatás and Mihov (2001b), Canzoneri et al. (2002), Mountford and Uhlig (2009), Dupor and Li (2015), Ricco et al. (2016), Jorgensen and Ravn (2019) and D'Alessandro et al. (2019) find that the same shock decreases prices/inflation.

On the real exchange rate, Kim and Roubini (2008) found that fiscal expansions depreciate the real exchange rate. This result has then been confirmed by Monacelli and Perotti (2010), Enders, Muller and Scholl (2011), Ravn, Schmitt-Grohe and Uribe (2012) and Ilzetzki, Mendoza and Vegh (2013). However, Auerbach and Gorodnichenko (2016) show that unanticipated shocks to announced military spending cause an appreciation of the U.S. dollar. Born et al. (2013) and Born et al. (2019) also point out that under a fixed exchange rate regime the real exchange rate appreciates and Ilzetzki and Jin (2013) found that the response of the real exchange rate depends on the sample considered. Then, in line with different conditional responses, Kim (2015), Forni and Gambetti (2016), Miyamoto, Nguyen and Sheremirov (2019), Boehm (2019) and Lambertini and Proebsting (2019) argue that the response of the exchange rate depends on country characteristics, like the stage of economic development, the timing of the fiscal shock (namely if it is anticipated or not) and the sign or type of fiscal instrument (government consumption or investment).

This paper re-examines and merges the closed and open economy debate by employing a different identification scheme to estimate the impact of fiscal spending shocks on inflation and the real exchange rate. The military narrative series constructed by Ramey (2011) and Ramey (2016a), after having showed that is a valid instrument for unanticipated fiscal shocks, is used into a Vector Auto-Regression, employing the proxy-SVAR 
methodology developed by Mertens and Ravn (2013) and Stock and Watson (2008). Using this identification technique, most puzzling results dissolve: government spending shocks are inflationary, appreciate the real exchange rate, worsen the trade balance and decrease private consumption. These dynamics are aligned with standard theoretical predictions and the responses of an estimated real business cycle open economy model match surprisingly well empirical impulse-responses. The contribution of the paper can be seen as a reconciliation of empirical results with standard theories or, more simply, as an incitement to further research on the joint response of domestic and international prices to fiscal shocks.

Specifically, the proxy-SVAR is estimated on quarterly United States data using a Bayesian approach over the 1964Q1-2015Q4 period. Two important aspects should be emphasised at the very outset. First, even though Ramey (2016a) has constructed the narrative series to instrument both contemporaneous and anticipated government spending, we use it here to instrument only unanticipated shocks. We show that this series is indeed a valid instrument for contemporaneous government spending in the 1964-2015 period, satisfying both the relevance and the exclusion restrictions. Second, given the importance of the time-frame for fiscal estimates, we pick as a baseline the 1964Q1-2015Q4 period to use the official real effective exchange rate data from the Bank of International Settlement (BIS), available at the earliest from 1964.

Multiple robustness checks are also included. Theory-consistent responses to a positive government spending shock are also found when the estimation is carried out in the post-1976 sample (which excludes the Bretton-Wood's period, Kim et al., 2017) or when we exclude the Great Recession period (i.e. with sample ending in 2006). Using nominal exchange rates or using a different definition of inflation does not change the result. Moreover, using defense government investment, instead of Ramey (2016a)'s narrative series, as an instrument for government spending (as in Miyamoto et al. (2019)) also confirms our results (Section 4).

Finally, in order to check the theoretical coherence of our empirical estimates, we set up a standard two-good RBC small open economy model and estimate it to match the impulse-responses to a government spending shock. This exercise allows us to first, estimate three critical parameters governing the response of the real exchange rate, consumption and the trade balance: the trade elasticity, the persistency of the shocks and the wealth elasticity of labor supply (see Corsetti et al., 2008 and Monacelli and Perotti, 2010). Second, it enables us to get an immediate feeling on how far we can go in explaining empirical results with a standard and frictionless framework. Impact responses, with the exception of GDP (not surprisingly), are impressively well described by a standard 
estimated open real business cycle model.

Related Literature - Our paper draws on different strands of literature. First, it is closely related to the literature analyzing the empirical effects of fiscal policy on the real exchange rate and inflation. The seminal paper focusing on exchange rate responses is Kim and Roubini (2008), where the authors document a US real exchange rate depreciation following a positive US fiscal shock, at odds with what the theory predicts. They also document a counterintuitive reaction of the trade balance, which improves instead of deteriorating. Such puzzling results ignited a stream of the literature which mainly confirmed these empirical regularities. Monacelli and Perotti (2010) find that, in the US and other advanced economies, a rise in government spending induces a depreciation of the CPI real exchange rate and a trade balance deficit. They also find that private consumption rises in response to a government spending shock, in line with Blanchard and Perotti (2002) and Ravn, Schmitt-Grohé and Uribe (2006). Ravn et al. (2012) use a panel structural VAR analysis to document that an increase in government purchases raises output and private consumption, deteriorates the trade balance, and depreciates the real exchange rate, both in the US and in other four industrialized countries. Enders et al. (2011) find, using sign restrictions, that the exogenous expansions of government spending depreciates the real exchange rate and the terms of trade. Ilzetzki et al. (2013) concentrate on the output effect of fiscal policy, but it highlights the same puzzling response of the real exchange rate, using a panel of 44 countries. More recently, Kim (2015) investigated again the question, examining 19 OECD countries. The author finds that current account worsens and real exchange rate appreciates in the majority of the countries, but various country characteristics (e.g. trade openness, capital mobility, etc.) are driving the result. Similarly, Miyamoto et al. (2019) explore the response of the exchange rate to a government spending shock differentiating between advanced and emerging countries. They identify the shock using annual military expenditures and find an appreciating (depreciating) exchange rate in emerging (advanced) economies. Even if focusing on a different aspect, Boehm (2019) shows that a government investment shock, and not a government consumption shock, can slightly appreciate the real exchange rate when the country has a floating nominal exchange rate (based on Ilzetzki et al. (2017)). Born et al. (2013) and Born et al. (2019) confirm that real exchange rate responses is conditional on the exchange rate regime but also show an asymmetry due to the sign of the government spending shock. Finally, Lambertini and Proebsting (2019) find that government spending shock cause an appreciation of the exchange rate in a fixed exchange rate regime.

However, the two papers closest to our findings in terms of exchange rate responses 
are Auerbach and Gorodnichenko (2016) and Forni and Gambetti (2016). Auerbach and Gorodnichenko (2016) use daily data on U.S. defense spending and documents that the dollar immediately and strongly appreciates after announcements of future government spending. On the contrary, when actual payments are made, spending variations have no significant effects on the exchange rate. Forni and Gambetti (2016) use the Survey of Professional Forecasters to account for both government spending anticipated and surprise shocks. They estimate the effects of both types of shocks using a quarterly VAR from the 80 's, finding that anticipated shocks generate an appreciation of the real exchange rate, while surprise shocks generate a depreciation.

Moving to the effects of fiscal policy on inflation, results are also mixed. Edelberg et al. (1999), Zeev and Pappa (2017) and Caldara and Kamps (2017) find that a government spending shock increases prices/inflation. Other studies, like Fatás and Mihov (2001a), Perotti (2005), Canova and Pappa (2007) and Nakamura and Steinsson (2014) find either a non-significant response or mixed evidence. However, a large set of papers (i.e. Fatás and Mihov (2001b), Canzoneri et al. (2002), Mountford and Uhlig (2009), Dupor and Li (2015), Ricco et al. (2016), Jorgensen and Ravn (2019) and D'Alessandro et al. (2019)), find that a government spending shock is deflationary. In particular, Jorgensen and Ravn (2019), using data from the 80's and adopting various identification schemes, document that in response to an increase in government spending, inflation falls. They rationalize the negative behavior of inflation by showing that a fiscal shock increases domestic productivity, hence generating a supply side boost which more than compensate the increase in aggregate demand. Similar results are found by D'Alessandro et al. (2019), which develops a quarterly Bayesian VAR including fiscal and TFP variables for the period 1954Q3-2007Q4, finding that inflation turns negative after a positive fiscal shock.

Clearly, our paper is also related to the literature on the estimation methods of fiscal policy shocks. One common feature over most of the aforementioned papers is the identification methods adopted in order to recover the structural fiscal shock. These are based on the Blanchard and Perotti (2002) restrictions on the variance-covariance matrix or on sign restrictions (Mountford and Uhlig, 2009) or on narrative identification methods (Romer and Romer, 2010). In this paper we will differentiate ourselves by adopting the proxy-SVAR methodology, developed independently by Mertens and Ravn (2013) and Stock and Watson (2008), which combines the narrative series of Ramey (2011) and Ramey (2016a) with the SVAR structure, on a long sample.

It is important to mention that our focus on the real exchange rate, and consequently on net exports, interrelates our paper to the literature studying fiscal spillovers. Corsetti et al. (2009), Corsetti et al. (2011), Corsetti and Muller (2013), Auerbach and Gorod- 
nichenko (2013) and Faccini et al. (2016) study the role of fiscal policy in a increasing globalized world, highlighting different transmission mechanisms. Here we simply show that a government spending shock appreciates the exchange rate and decreases net demand for foreign goods, which will therefore have an impact (that we don't estimate) on other economies.

Last, our paper is related to the theoretical literature analyzing the economic effects of fiscal policies. A standard closed economy neo-classical model (Baxter and King, 1993) would suggest that an increase in unproductive government spending would generate a fall in private consumption (via a negative wealth effect due to the increase in the present value of taxes to be paid) and an increase in prices. Empirically, however, most of the evidence pointed towards an increase in private consumption and a fall in prices in response to a positive government spending shock. This mismatch between theory and empirics has been shaping theoretical studies, which tried to rationalize the empirical findings (see, for example, Basu and S. Kimball, 2003, Linnemann, 2006, Ravn et al., 2006, Galí et al., 2007 and more recently Jorgensen and Ravn, 2019 and D'Alessandro et al., 2019). A similar contrast between theoretical predictions and empirical evidence drove also the theoretical literature looking at the impact of fiscal policy in open economies. A benchmark general equilibrium open economy model featuring complete financial markets would imply that an increase in government spending would generate an appreciation of the exchange rate, a fall in the trade balance and a fall in consumption. Empirically, however, the evidence was pointing towards a depreciation of the real exchange rate, an increase in the trade balance and an increase in consumption. Monacelli and Perotti (2008) and Monacelli and Perotti (2010) describe well the empirical vs theoretical inconsistencies: benchmark open economy models including the wealth effect of government spending and perfect risk-sharing across countries cannot rationalize simultaneously the effects on quantities and relative prices, and even more so if government spending is intensive in non-traded goods. To solve these issues, two theoretical solutions have been proposed: first, counteract the negative wealth effect coming from government spending by assuming non-separable utility or equilibrium variable markups (Monacelli and Perotti, 2010); second, calibrate the model with a low trade elasticity (Enders et al., 2011). To insert our paper within this debate, we will set up a model accounting for the possibility of these features and we will estimate their relevance via an impulse-responses matching procedure.

The rest of the paper is organized as follows. Section 2 briefly describes the proxySVAR methodology, the identification strategy, the data and specification adopted in the paper. Section 3 presents the empirical results. Section 4 shows the robustness of the 
results to different specifications. Section 5 matches the theoretical and empirical impulseresponses by estimating a standard two-good RBC small open economy model. Finally, Section 6 concludes.

\section{Empirical model and identification strategy}

In this Section we introduce our empirical model and the identification strategy. First, we briefly describe the proxy-SVAR methodology. Second, we present our set of target variables. Third, we discuss the use of the military narrative series as an instrument for unanticipated government spending shocks.

\subsection{The proxy-SVAR framework}

Consider the following Vector AutoRegressive (VAR) model:

$$
X_{t}=c_{0}+\sum_{k=1}^{P} A_{k} X_{t-k}+u_{t} \quad u_{t} \sim N\left(0, \Sigma_{u}\right)
$$

where $X_{t}$ is a vector of endogenous variables, $c_{0}$ is a constant vector, $A_{k}$ are the matrices containing the reduced-form parameters, $u_{t}$ is the vector of reduced-form residuals and $\Sigma_{u}$ is the covariance matrix of the reduced-form shocks. In order to identify structural shocks in the VAR, one needs to specify a matrix $P_{0}$ that pre-multiplying Equation 1 yields:

$$
P_{0} X_{t}=P_{0} c_{0}+P_{0} \sum_{k=1}^{P} A_{k} X_{t-k}+\epsilon_{t}
$$

where $\epsilon_{t}=P_{0} u_{t}$ is the vector of structural shocks with mean zero and covariance matrix $\Sigma_{\epsilon}$. To construct the matrix $P_{0}$, to identify fiscal shocks in the United States, we use the proxy-SVAR methodology, developed by Mertens and Ravn (2013) and Stock and Watson (2008). Restrictions on $P_{0}$ are obtained by making use of a proxy of the true latent exogenous variable. We employ a narrative measure $m_{t}$ to proxy for the unobserved fiscal shock $\epsilon_{f, t}$, where we assume $E\left(m_{t}\right)=0$; In addition, denoting the non-fiscal US shocks as $\epsilon_{n f, t}$, our narrative measure needs to satisfy the following two conditions:

$$
\begin{aligned}
E\left[m_{t}, \epsilon_{f, t}\right] & =\gamma \\
E\left[m_{t}, \epsilon_{n f, t}\right] & =0
\end{aligned}
$$

This means that our proxy $m_{t}$ is correlated with the unobserved fiscal policy shock but 
it is orthogonal to the remaining shocks. This methodology provides the restrictions for the columns of the matrix $P_{0}$ related to the fiscal variable. To obtain them, we follow the standard two-step procedure for proxy-SVARs: first, we run a two-stage least squares (2SLS) estimation of all non-fiscal residuals in the US model $\left(u_{n f, t}\right)$ on the fiscal ones, using $m_{t}$ as an instrument for $u_{f, t}$ : the estimated coefficients represent each variables' restrictions up to a scale factor; second, we impose covariance restrictions to identify each element in the $l^{\text {th }}$ column of $P_{0}$. Details on the proxy SVAR procedure are reported in Mertens and Ravn (2013).

\subsection{Data and specification}

Narrative measures of fiscal policy changes, both for taxes and spending shocks, have been constructed in the literature from historical sources. These measures are imperfectly correlated with latent structural policy shocks, mostly because of measurement errors: historical records sometimes contradict each other and disregard minor policy changes. Using a proxy-SVAR approach has the advantage of extending the use of proxy series to cases where we know that these narrative series are measured with errors. In the literature this methodology has been used to proxy tax shocks while here we extend it to identify unanticipated government spending shocks (see Section 2.3). Against this backdrop, we use the military spending narrative series constructed by Ramey (2016a).

The baseline specification of our VAR model encompasses the following US variables: real government spending $G_{t}$, real GDP $y_{t}$, tax revenues $t a x_{t}$, real private consumption $c_{t}$, inflation $\pi_{t}$, total factor productivity (TFP) $t f p_{t}$, trade balance (in percent of GDP) $T B_{t}$, the stock price of Boeing (proxying the market value of the military firms sector) $s_{t}$ and the narrow real effective exchange rate of the dollar reer ${ }_{t}{ }^{1}$ With the only exception of inflation and the trade balance-to-GDP ratio, all other variables are taken in logs. Inflation is computed on an annual basis using the personal consumption expenditure (PCE) deflator. Real government spending, real GDP and real tax revenues are obtained by deflating nominal variables using the GDP deflator; differently, private consumption is deflated using the PCE deflator. The TFP variable is taken from Fernald (2012), and the military narrative series stems from Ramey (2016a). Nominal GDP, government spending and tax revenues are taken from Ramey and Zubairy (2018). Stock prices are taken from Yahoo!Finance. The real effective exchange rate, as well as the nominal exchange rate used in a robustness check, are taken from the BIS database. Data on nominal defense government investment, used in another robustness section, are deflated with the

\footnotetext{
${ }^{1}$ The broad effective exchange rate is only available starting in 1994.
} 
defense consumption and investment deflator; both the defense and deflator variables are taken from the FRED database.

We estimate the model on quarterly data and, as it is standard in the literature, we include the constant and four lags of the endogenous variables. The baseline estimation sample ranges from 1964Q1 to 2015Q4. ${ }^{2}$ We exclude from the sample the years of the recent financial crisis, i.e. from 2007Q3 to 2009Q4. The model is estimated using Bayesian techniques, performed via a block MCMC algorithm. We use the dummy method of Del Negro and Schorfheide (2011) and Caldara and Kamps (2017) and we impose a Minnesota prior on the reduced-form VAR parameters; in addition, we choose the hyperparameters governing the prior distributions in order to impose relatively weak priors.

\subsection{The narrative series in the proxy-SVAR framework}

Puzzling results on the response of inflation and exchange rate have be found in the literature in reaction to surprise, contemporaneous, government spending shocks. We therefore want to focus on these shocks. Consistently, the use of a proxy-SVAR allows us to extract from a narrative series the information to instrument current (and not future) fluctuations.

To proxy contemporaneous US government spending shocks, however, we use the Ramey (2016a) narrative series which has been constructed to capture the net present value of both current and expected military expenditures (i.e. surprise plus anticipated movements). We therefore need to explain and support our choice. The argument prompted by Ramey (2016a) and Ramey and Zubairy (2018) is that during the largest military episodes of the recent US history, in particular World War II and the Korean War, long lasting military spending have been anticipated by information reported in the press. In line with this reasoning, Ramey and Zubairy (2018) show that when war episodes are included in the sample, the narrative series they construct is in fact a valid instrument for future government spending. This is clearly visible by looking at the red-dotted line in Figure 1, where we replicate Ramey (2016b) F-test results (here reported in relative terms to the appropriate critical value) of a regression of government spending over controls (tax revenue and GDP) and the military narrative series: when the sample starts in 1947, the narrative measure is good at explaining future government spending movements.

Provided that real effective exchange rates for the United States are not available from official sources before 1964, we focus our attention on a shorter sample, which does not

\footnotetext{
${ }^{2}$ As already anticipated, such sample interval is the widest possible given the constraints on data availability: data on real effective exchange rate starts in 1964Q1 and the narrative military series ends in 2015Q4.
} 


\section{Relative F-statistics with respect to the appropriate critical value}

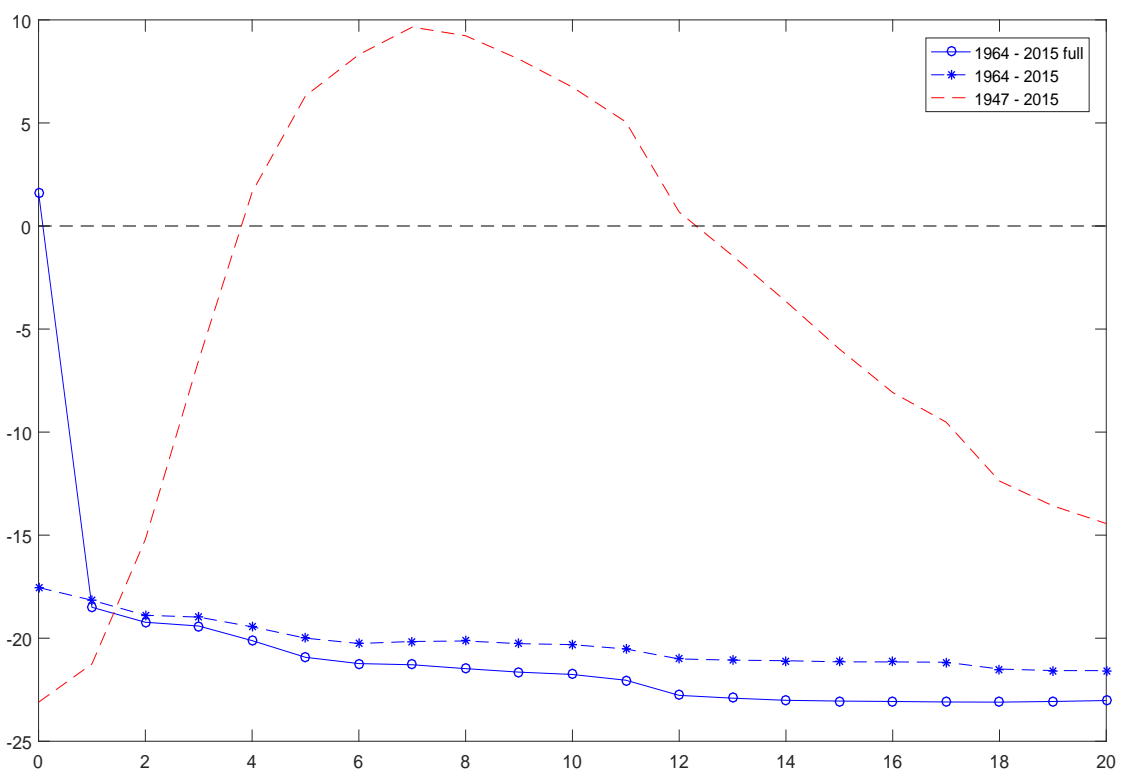

Figure 1: F-statistics (in deviations from their critical values) over h-horizons. First-stage F-statistics for government spending shocks. The F-statistics are based on the regression of the sum of government spending from $t$ to $t+h$ on the military narrative series at $t$, plus 4 lags of control variables (equation 5). Controls for the 1964-2015 and 1947-2015 specifications (blue and red dotted lines) are tax revenue and GDP, while the 1964-2015 full specification (blue solid line) has additional controls (inflation, TFP, consumption, short term interest rate, the stock price of defense military firms and the real exchange rate). The horizontal dashed line at zero is the weak instrument threshold. A value above zero indicates that the test accepts the instrument to be a valid one.

include war episodes. This should push towards the use of the narrative series as an instrument for unanticipated shocks, following Ramey and Zubairy (2018) argument. We test this hypothesis by running an F-test on our time-frame, to check the strength of the instrument for unanticipated fluctuations. We proceed as follow: we regress cumulated spending on the military narrative series at time $t$ and four lags of control variables. This regression can be written as

$$
\sum_{j=0}^{h} g_{t+j}=\gamma_{h}+m_{h} \text { narrative }_{t}+\phi_{h}(L) z_{t-1}+\omega_{t+h}
$$

where $\sum_{j=0}^{h} g_{t+j}$ is the sum of current and future government spending, narrative ${ }_{t}$ is the 
military narrative series and $z_{t-1}$ is the set of lagged controls. ${ }^{3}$ The test is computed against an alternative specification which excludes the narrative series from the set of regressors, i.e.

$$
\sum_{j=0}^{h} g_{t+j}=\gamma_{h}+\phi_{h}(L) z_{t-1}+\omega_{t+h}
$$

We run three specifications of the F-test: first, on the 1947-2015 sample, using only tax revenue and GDP as controls (Ramey and Zubairy, 2018); second, employing the same specification but on the 1964-2015 period; Third, on the same 1964-2015 sample but enriching the set of controls with all variables that are included in our baseline SVAR.

Results of the F-tests, each of them conducted with $h=20$ (i.e. from 0 - to 20-quarter horizon), are displayed in Figure 1. The Figure reports the F-statistics minus the appropriate critical value threshold. This means that, according to whether residuals of Equation (5) should have a different critical values (i.e. because they are autocorrelated or not), each point of the F-test is plotted with respect to its appropriate critical value (see Montiel Olea and Pflueger (2013)).

To test for autocorrelation, we run the Ljung-Box Q-test on the three F-test specifications, one for each $h$ series of residuals $\omega_{t+h}$. Results, available upon request, show that residuals of h-quarter ahead predictive regressions (with $h>0$ ) are all autocorrelated. This is the case by construction, as control variables do not include time $t+h-1$ observations. Concerning contemporaneous regressions (i.e. $h=0$ ), residuals are still autocorrelated if we control for only tax revenues and GDP, as in Ramey and Zubairy, 2018. They become non-autocorrelated only when inflation, real exchange rate and consumption are also included as control variables. Even though this set of variables would be sufficient to avoid autocorrelation, we include as controls all variables of our SVAR specification, following Stock and Watson (2018) reasoning that this improves test precision. ${ }^{4}$ As a result, the (lower) critical value for serially uncorrelated error terms is considered only for impact F-statistics (i.e., $h=0$ ) in the 1964-2015 specification with the full set of controls (third specification). In all other cases, the significance of the F-test is judged with respect to the threshold of autocorrelated error terms. ${ }^{5}$

\footnotetext{
${ }^{3}$ The findings from the F-tests are robust to the alternative specification of the dependent variable as $g_{t+j}$ instead of $\sum_{j=0}^{h} g_{t+j}$.

${ }^{4}$ It is worth adding two things: first, results do not change when the F-test is performed on the only post Bretton-Woods period, which ensures that our instrument is a valid one also when considering the flexible exchange rate regime period; second, results hold also when we add among the set of controls the principal components extracted from the dataset of macroeconomic variables of McCracken and $\mathrm{Ng}$ (2016). Both these exercises improve F-test results.

${ }^{5}$ For the serially uncorrelated case, we apply the threshold of Montiel Olea et al. (2018) - i.e. 3.84. For the
} 
By reporting relative F-statistics, the zero line in Figure 1 represents the meaningful threshold to test for weak instrument. A value above zero indicates that the test accepts the instrument to be a valid one. Two facts emerge from the analysis: (i) in the 1964-2015 sample, the narrative series is a valid instrument only when instrumenting contemporaneous government spending (first point of the solid blue line); (ii) the narrative series is a valid instrument for anticipated government spending only when including wars (dashed red line) and this is not anymore the case for the 1964-2015 sample. Over this period, the narrative series has no relevance at future horizons. One possible reason for this finding could be related to a decrease in the implementation lag of some types of military expenditures outside war episodes. All in all, our results suggest that the military narrative series constructed in Ramey (2016a) is a valid instrument for future spending when the sample starts before the Korean-war but it is a relevant instrument for current government spending when considering a more recent sample.

To exclude the possibility that our proxy is an instrument also for variables other than government spending, we repeat our F-tests by substituting $g$ with one of the other variable at a time on the left hand side of Equations 5 and 6. Results, displayed in Figure 7 in Appendix A, show that the F-test fails for all variables at all horizons but for contemporaneous government spending. ${ }^{6}$

Finally, another potential issue lying in our identifcation strategy relates to non fundamentalness, as highlighted by Forni and Gambetti (2014). Indeed, if a VAR model does not contain sufficient information, it is not possible to recover the true structural shocks. Forni and Gambetti (2014) show the necessary and sufficient conditions under which the VAR is invertible and propose a test to detect non-fundamentalness. ${ }^{7}$ The idea of the test rests on the assumption that structural shocks $\epsilon_{t}$ cannot be Granger-caused by any other variable. In the spirit of Forni and Gambetti (2014) we project the recovered structural spending shock, estimated in the next section, on the lagged principal components extracted from a large dataset of macro variables (McCracken and Ng, 2016), which summarize the information set of the econometrician. In order to assess fundamentalness in our environment we test whether the coefficients $\psi$ in the following regression are jointly significant:

other cases we use the one proposed by Montiel Olea and Pflueger (2013), and used in Ramey and Zubairy (2018), which is 23.1085.

${ }^{6}$ We also implement the frequentist testing procedure of Lunsford (2016), projecting the proxy variable on the VAR reduced-form residuals, and we obtain an F-statistic of 2.7, a value below the 4.48 proposed threshold. However, differently from Lunsford (2016), our residuals are estimated using Bayesian inference.

${ }^{7}$ Canova and Sahneh (2018) propose an alternative method to test for non-fundamentalness in smallscale SVAR. 


$$
\epsilon_{t}=\delta+m_{h} \sum_{j=1}^{n P C} \psi_{j} \mathrm{PC}_{j, t-1}+\phi_{t}
$$

where $\delta$ is a constant, $P C$ stands for the principal components and $n P C$ is the number of PC considered. The F-statistic is 0.0188 , failing to reject the null hypothesis of fundamentalness.

\section{Empirical Results}

This section presents the main results from the empirical analysis. Responses to a government spending shock identified through the proxy-SVAR methodology are compared with responses stemming from a standard Cholesky identification method. Then, in the following section, we provide empirical evidence on the robustness of our results.

\subsection{Impulse response functions}

We start by showing standard puzzling results. Figure 2 reports responses to a one standard deviation positive shock to US government spending, using the recursive Cholesky identification method on the 1964-2015 sample. The real exchange rate depreciates (here defined as number of foreign goods for domestic ones), inflation falls, trade balance improves and consumption increases.

Figure 3 displays instead the responses of the same variables (on the same sample) when the fiscal shock is identified using the proxy-SVAR methodology. We find that the real exchange rate appreciates, inflation increases, trade balance deteriorates and consumption falls.

Dissecting the result, the real exchange rate appreciation is driven both by the response of inflation and by the nominal effective exchange rate (see Figure 4), in line with Mussa (1986). Inflation increases on impact and becomes not significant after few quarters. The fall in trade balance supports the twin deficit hypothesis, coherently with the appreciated real exchange rate, and contrasts the alternative twin divergence hypothesis (Kim and Roubini, 2008). Consumption decreases, in line with Ramey (2011), confirming the crowding-out effect due to the increase in the present value of taxes to be paid. This is true for both consumption of durables and consumption of non-durables and services (Figure 8 in Appendix B). TFP, in line with Jorgensen and Ravn (2019), augments. However, dif-

ferently from them, the increase in supply, due to the TFP increase, does not overcome the positive increase in demand from government spending and therefore prices increase. 

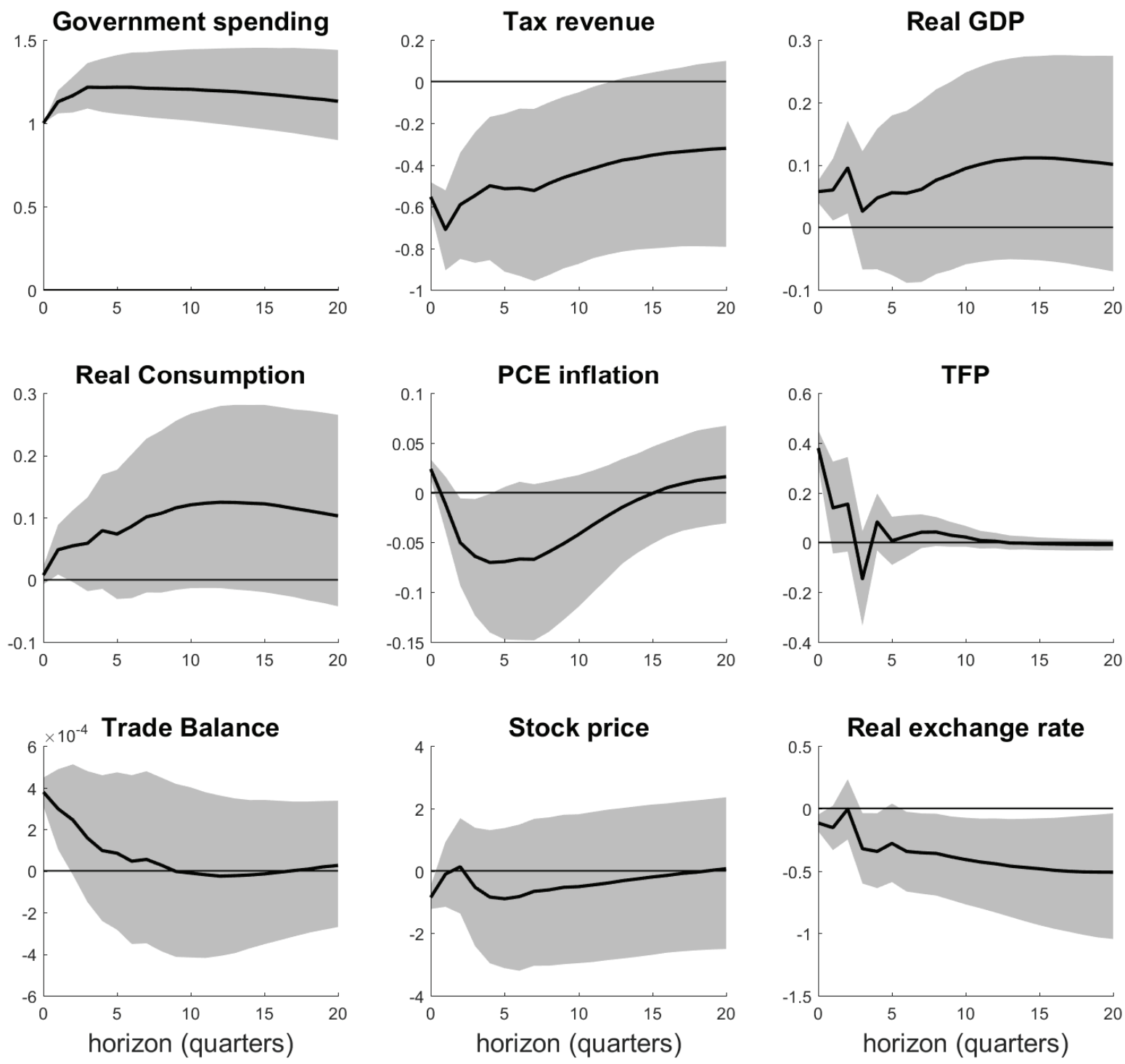

Figure 2: Cholesky identification. Impulse responses from a one standard deviation government spending shock. Target variables are tax revenues, real GDP, real private consumption, PCE inflation, total factor productivity, trade balance, stock prices of military firms and real effective exchange rate. The real effective exchange rate is defined as the weighted basket of foreign goods to domestic goods: a decrease stands for a depreciation. The impulse responses are obtained in a VAR framework with the spending shock identified through the Cholesky scheme. Shaded bands denote the $68 \%$ pointwise credible sets.

The remaining variables show a standard behavior. Economic activity increases on impact, implying a fiscal multiplier slightly below 1 , and then becomes insignificant. The stock price index of military firms also increases, confirming the non-anticipated compo- 


\section{Bayesian Proxy-SVAR (1964Q1-2015Q4)}
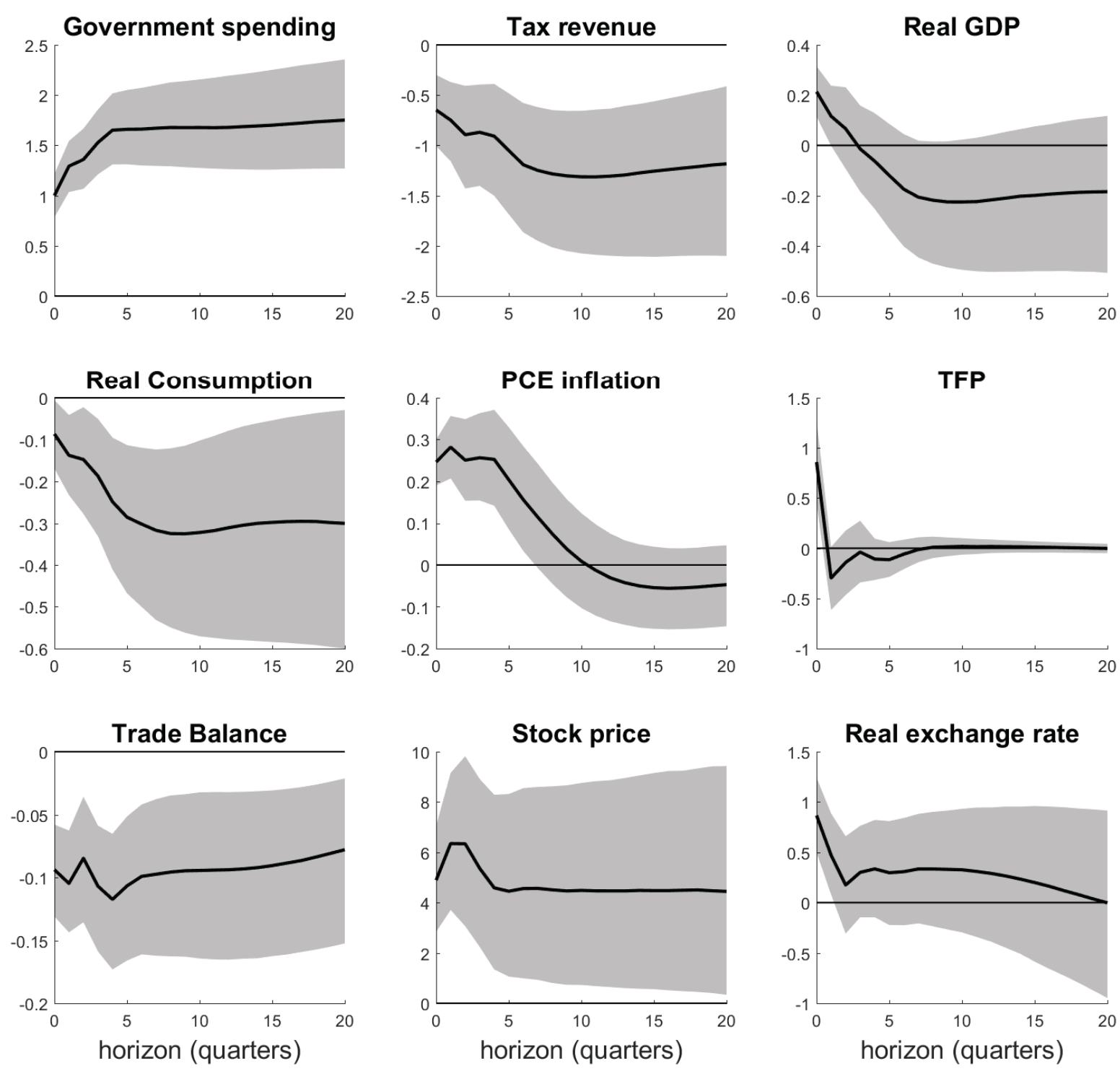

Figure 3: Proxy-SVAR narrative identification. Impulse responses from a one standard deviation government spending shock. Target variables are tax revenues, real GDP, real private consumption, PCE inflation, total factor productivity, trade balance, stock prices of military firms and real effective exchange rate. The real effective exchange rate is defined as the weighted basket of foreign goods to domestic goods: an increase stands for an appreciation. The impulse responses are obtained in a proxy-SVAR framework in which government spending is instrumented with the military narrative series of Ramey (2016a). Shaded bands denote the $68 \%$ pointwise credible sets.

nent in the identified shock. Finally, tax revenues decrease. ${ }^{8}$

${ }^{8}$ Appendix $C$ shows the response of investment. An increase in government spending crowds-out investment, in line with a standard Real Business Cycle model. 


\section{Robustness}

This section reports additional evidence to support our baseline result, i.e. that the real exchange rate appreciates and inflation reacts positively after a spending shock. We propose two additional sets of impulse responses. The first one is constructed using the same identification scheme of the baseline model but changing samples length or variables specification (i.e. excluding the Bretton-Woods or the Great Recession, defining inflation as the consumer price index and focusing on the nominal exchange rate). The second one uses defense government investment, instead of the narrative military series of Ramey, 2016a, to instrument surprise government spending shocks. Results are robust.

\subsection{Other VAR specifications}

Figure 4 shows the impulse-responses of our proxy-SVAR re-estimated on four different model specifications: 1) Excluding the Bretton-Woods period - 1976Q1-2015Q4. This has the advantage of focusing on a sample with only floating exchange rates and of being directly comparable with Kim and Roubini (2008); 2) Excluding the Great Recession 1964Q1-2006Q4. This allows us to exclude the financial crisis and its, maybe, different behavior; 3) Substituting the real effective exchange rate with the nominal one; 4) Replacing the Personal Consumption Consumer Index with a more standard Consumer Price Index to measure inflation. For conciseness, Figure 4 reports only the main variables of interest, i.e. the spending shock, the exchange rate, the trade balance and inflation. All other variables are available upon request.

The shock is inflationary, appreciates the real (or nominal) exchange rate and deteriorates the trade balance in all four specifications.

\subsection{Government defense investment as an instrument}

In order to be sure that our results are not only driven by the Ramey (2016a) narrative series, we analyse the impulse responses to the same shock identified through a different instrument: the quarterly change in government defense investment (see Miyamoto et al., 2019). Being aware that government consumption and investment shock might have different characteristics (see Boehm, 2019), we need to test the relevance of this series as an instrument for overall spending. We perform a similar F-test to the one performed for the Ramey (2016a) narrative series: changes in government defense investment are found to be a strong and valid instrument for surprise government spending shocks. ${ }^{9}$ We then

\footnotetext{
${ }^{9}$ Results are available upon request.
} 

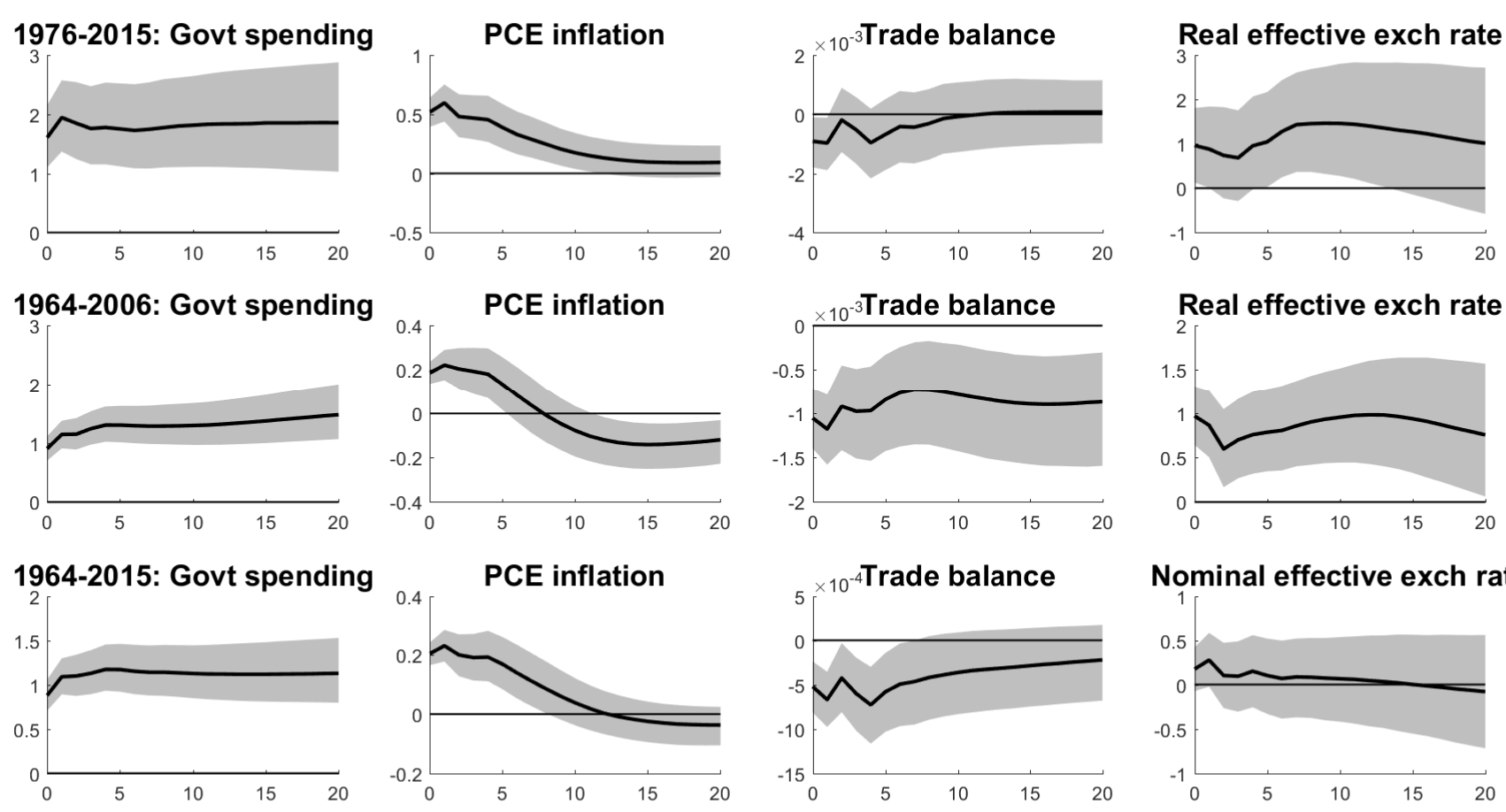

1964-2015: Govt spending
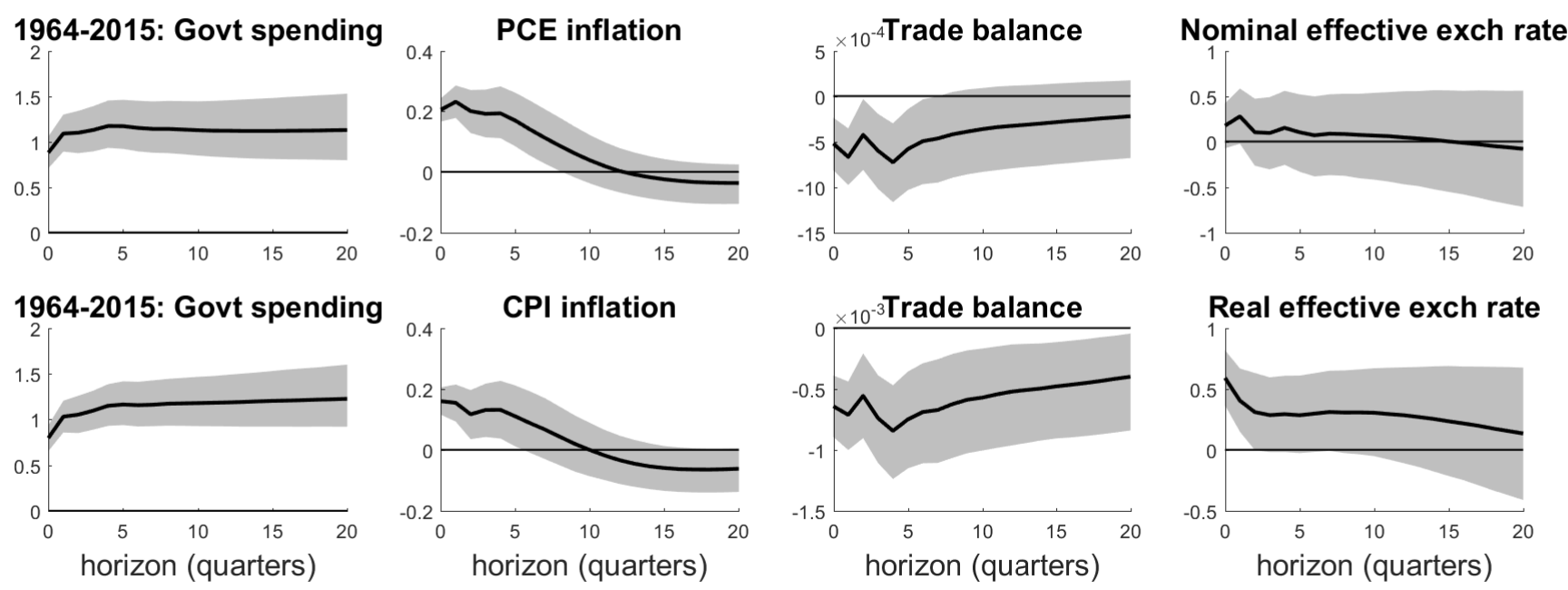

Figure 4: Robustness using narrative shocks. Impulse responses of government spending, inflation, trade balance and real effective exchange rate across different sample or variable specifications. The real effective exchange rate is defined as the weighted basket of foreign goods to domestic goods: an increase stands for an appreciation. Line 1: fully flexible exchange rate sample (1976Q1-2015Q4). Line 2: pre-crisis sample (1964Q1-2006Q4). Line 3: full sample, nominal (instead of real) effective exchange rate. Line 4: full sample, CPI (instead of PCE) inflation. The estimation sample for line 3 and 4 is 1964Q1-2015Q4. Shaded bands denote the $68 \%$ pointwise credible sets.

proceed, as before, estimating the Proxy-SVAR maintaining the same specification and estimation sample (1964Q1-2015Q4) of the baseline model.

Figure 5 shows the result. In response to a positive government spending shock, the real exchange rate appreciates, inflation increases and the trade balance deteriorates. 
Bayesian Proxy-SVAR - Government defense investment as an instrument
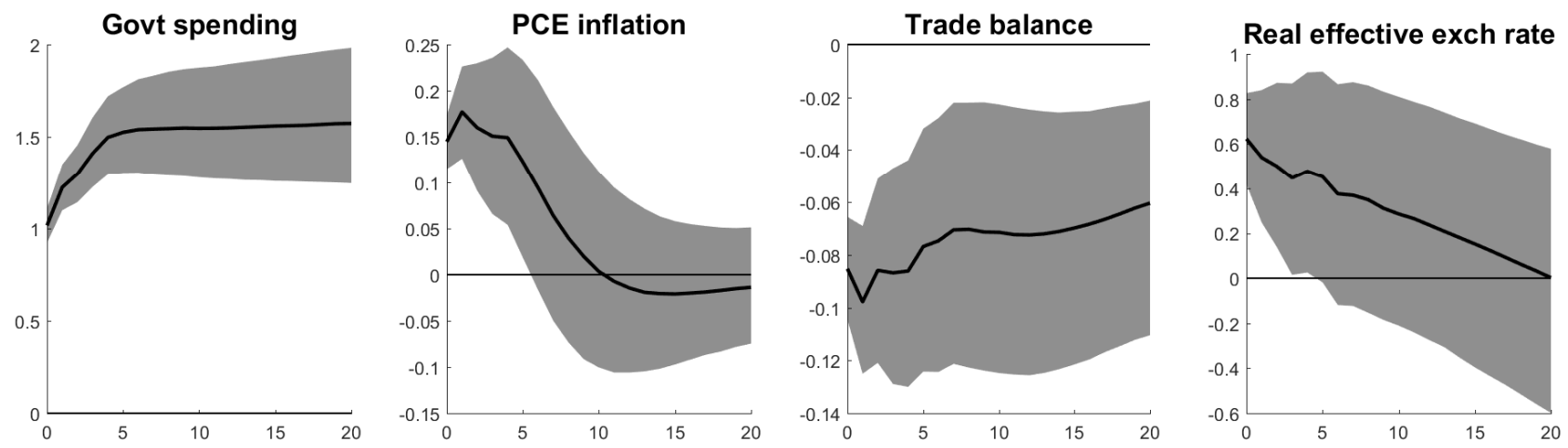

Figure 5: Robustness using defense investment. Impulse response functions constructed using defense investment as instrument for total government spending. The estimation sample is 1964Q1-2015Q4. The real effective exchange rate is defined as the weighted basket of foreign goods to domestic goods: an increase stands for an appreciation. Shaded bands denote the $68 \%$ pointwise credible sets.

\section{$5 \quad$ Theory and Empirical results - solving the puzzles}

Finally, to check the theoretical coherence of our empirical results, we build a standard RBC small open economy model. We then estimate its parameters to see how far we can go with a simple model in matching our empirical estimates. The results are quite striking: the simple model does a fair job in accounting for a broad range of macroeconomic responses to a government spending shock.

The model is the standard Small Open Economy Real Business Cycle model (see Mendoza, 1991 and Schmitt-Grohé and Uribe, 2017) enriched with multiple goods, as in Galí and Monacelli (2005), and a utility specification accounting for different degrees of wealth effects of government spending (Jaimovich and Rebelo, 2009). The economy is small, does not affect world prices and takes the world interest rate as given. This simplification, considering the focus on the U.S., is done to make our results comparable to Monacelli and Perotti (2010). However, as in Monacelli and Perotti (2010), results are not driven by the assumption of a small open economy. The model has three agents: household, firms and the government. International financial markets are incomplete and there are no nominal frictions. Households consume a composite of domestic and foreign goods, supply labor and save/borrow using a single internationally traded asset. They own the physical capital, rent it to firms and take investment decisions, which is subject to adjustment costs. Domestic firms produce a tradable good using capital and labor, selling it domestically and abroad. Movements in the terms of trade determine the competitiveness of the domestic sector, taking world demand as given. The government purchases domestic goods raising funds through taxes, running a balanced fiscal budget (Monacelli and Per- 
otti, 2010). The independence of the non-stochastic steady state from initial conditions is ensured through an endogenous discount factor, as in Schmitt-Grohé and Uribe (2003). Details on the standard model are available upon request.

\begin{tabular}{ccc}
\hline \hline \multicolumn{3}{c}{ Table 1. Estimated parameter values } \\
\hline \hline Parameter & Value & Standard Error \\
Trade elasticity & 0.694 & 0.096 \\
Capital adjustment cost & 0.714 & 0.032 \\
Wealth Elasticity & 0.894 & 0.1 \\
AR 1 & 1.41 & 0.081 \\
AR 2 & -0.416 & 0.1 \\
Inter-temporal elasticity of substitution & 0.644 & 0.042 \\
Home bias in consumption & 0.798 & 0.012 \\
\hline \hline
\end{tabular}

To contribute to the existing literature reconciling theory and empirical findings and to see how far a simple framework can account for our findings, we estimate seven crucial parameters: (1) the trade elasticity - governing (often together with the persistency of shocks) the response of households' demand (Corsetti et al. (2008); (2) capital adjustment cost - hindering the evolution of capital, affecting the correlation of macro variables' responses and the trade balance; (3) wealth elasticity of the labor supply - controlling the elasticity of the labor supply to wealth movements, setting the crowding out of government spending shocks; (4-5) Second order autoregressive process - shaping the response of government spending to its shock; (6) Inter-temporal elasticity of substitution - defining the inter-temporal behavior of consumption; (7) home bias in consumption - setting the share of domestic goods consumed in the basket of households. ${ }^{10}$

Parameters are estimated by matching the impulse-responses of six variables over twelve quarters: government spending, GDP, inflation, real exchange rate, trade balance and consumption. The estimated values of the parameters and their standard errors are reported in Table $5 .{ }^{11}$

Three are the main findings of the impulse-matching procedure. First, the trade elasticity is lower then one, consistently with most of theoretical international macro literature using simplified frameworks. Second, households' preferences display a quite large wealth effect in order to be consistent with the crowding out of consumption. Third, the labor elasticity, habits in consumption and the home bias are not extremely well identified using these responses to a government spending shock.

\footnotetext{
${ }^{10}$ We tried also to estimate the inverse of the Frisch elasticity and habits in consumption but these parameters are not identified using the IRF-matching procedure.

${ }^{11}$ Standard errors are computed using Altig et al. (2011) procedure.
} 
Model and empirical responses to a $1 \%$ increase in government spending ( $\%$ deviations)
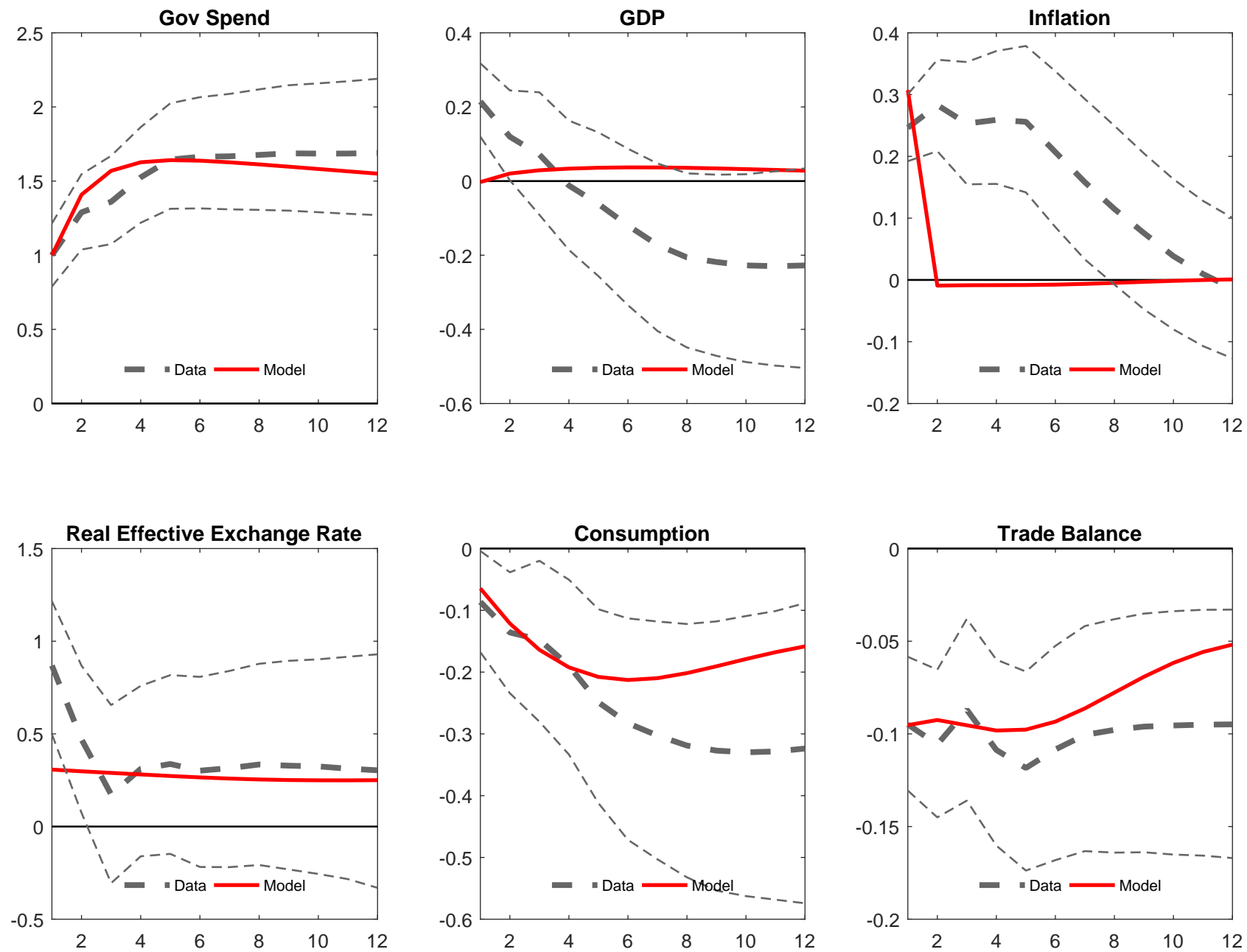

Figure 6: Impulse-response matching. Empirical (with lower and upper bound) vs. theoretical impulseresponses to one standard deviation shock to an unanticipated (unproductive) government spending shock.

Figure 6 compares the impulse-responses of the estimated model with empirical ones. The model matches, on impact, all signs of the responses and for all, with the exception of inflation and GDP, quite well also the dynamics. An increase in government spending is inflationary, appreciates the real exchange rate and, while increasing aggregate output, generates a fall in aggregate consumption. Focusing on inflation, the model is unable to explain the persistent inflation dynamics. However this is a feature of flexible prices, as, in absence of nominal rigidities, prices adjust immediately. As for GDP, given the almost frictionless model, the multiplier would be larger only in the presence of a quite high inter-temporal elasticity of substitution, a low trade elasticity and high capital adjustment costs. 


\section{Conclusions}

Starting from an extensive closed and open economy literature showing puzzling effects of government spending shocks on inflation and real exchange rate, we show that unanticipated changes in government spending have effects in line with standard theoretical results. The paper re-examines the effects of government spending shocks combining advantages of both narrative and VAR identification approaches, employing the proxySVAR framework. It first points out that defense spending press news, after 1964, are a valid instrument for unanticipated government spending shocks. Then, it shows that an increase in government spending is inflationary and appreciates the real exchange rate; besides it induces a trade balance deficit and a fall in consumption, of both durable and non-durable goods. Finally, these results are compared with a simple two-good standard small open economy RBC model, that, estimated to match empirical impulse responses, does a good job in explaining the sign and dynamics of macro responses. The contribution of the paper can be seen as a reconciliation of empirical results with standard theories or, more simply, as an incitement to further research on the joint response of domestic and international prices to fiscal shocks. 


\section{Appendix}

\section{A Test the narrative series as an instrument}

Here we report results of F-tests of Ramey (2016a) military series on all variables in our baseline VAR specification. The test shows for which variable our instrument is valid. The results, displayed in Figure 7, show that the narrative series is a good instrument only for government spending.

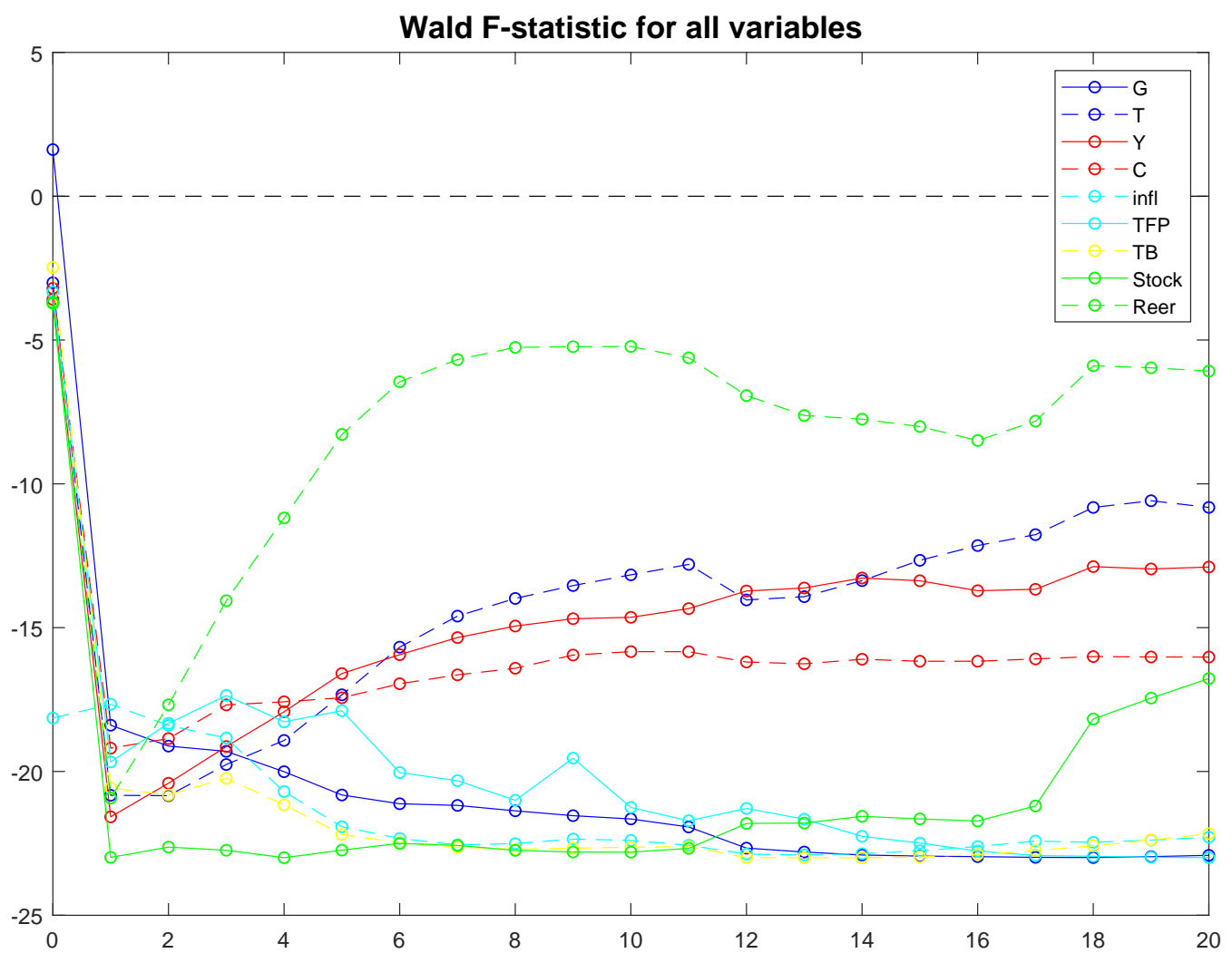

Figure 7: F-statistics (relative to the appropriate threshold) of tests conducted on all variables of our VAR specification. The F-statistics are based on equation 5. Controls are tax revenue, GDP, inflation, TFP, consumption, short term interest rate, the stock price of defense military firms and the real exchange rate. The horizontal dashed line at zero is the weak instrument threshold. A value above zero indicates that the test accepts the instrument to be a valid one. 


\section{B Consumption}

Figure 8 displays impulse-responses of the baseline specification where consumption is decomposed between non-durable + services and durable. All remaining variables are the ones included in the baseline specification. IRF are obtained using the proxy-SVAR methodology.
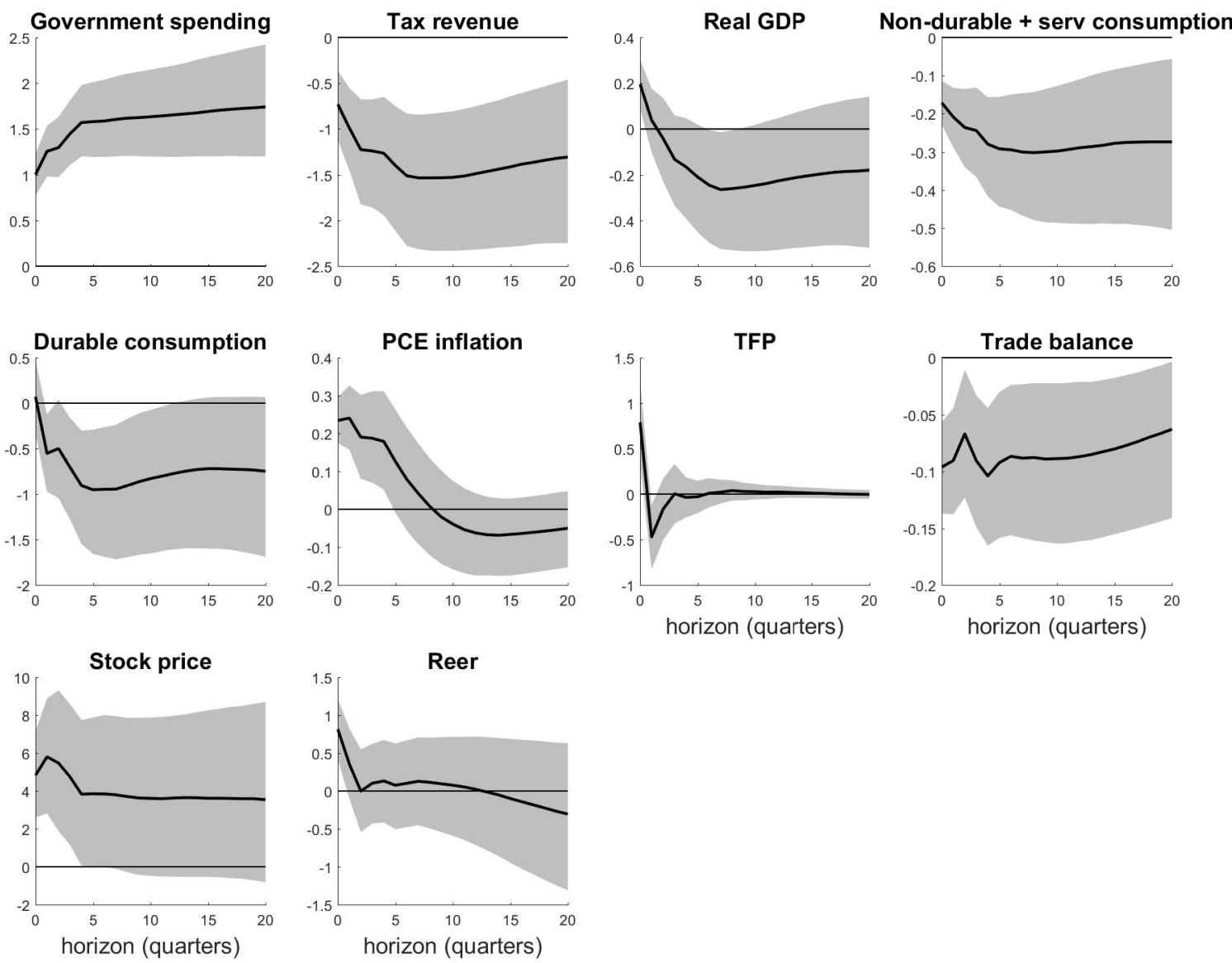

Figure 8: Consumption decomposition. Impulse responses from a one standard deviation government spending shock decomposing consumption. The real effective exchange rate is defined as the weighted basket of foreign goods to domestic goods: an increase stands for an appreciation. The impulse responses are obtained in a proxy-SVAR framework in which government spending is instrumented with the military narrative series of Ramey (2016a). Shaded bands denote the $68 \%$ pointwise credible sets. 


\section{Investment}

Figure 9 displays impulse-responses of tax revenues, real GDP, real investment, PCE inflation, total factor productivity, trade balance, short-term interest rate and real effective exchange rate to a government spending shock. IRF are obtained using the proxy-SVAR methodology. With respect to the baseline, consumption is here substituted with investment.
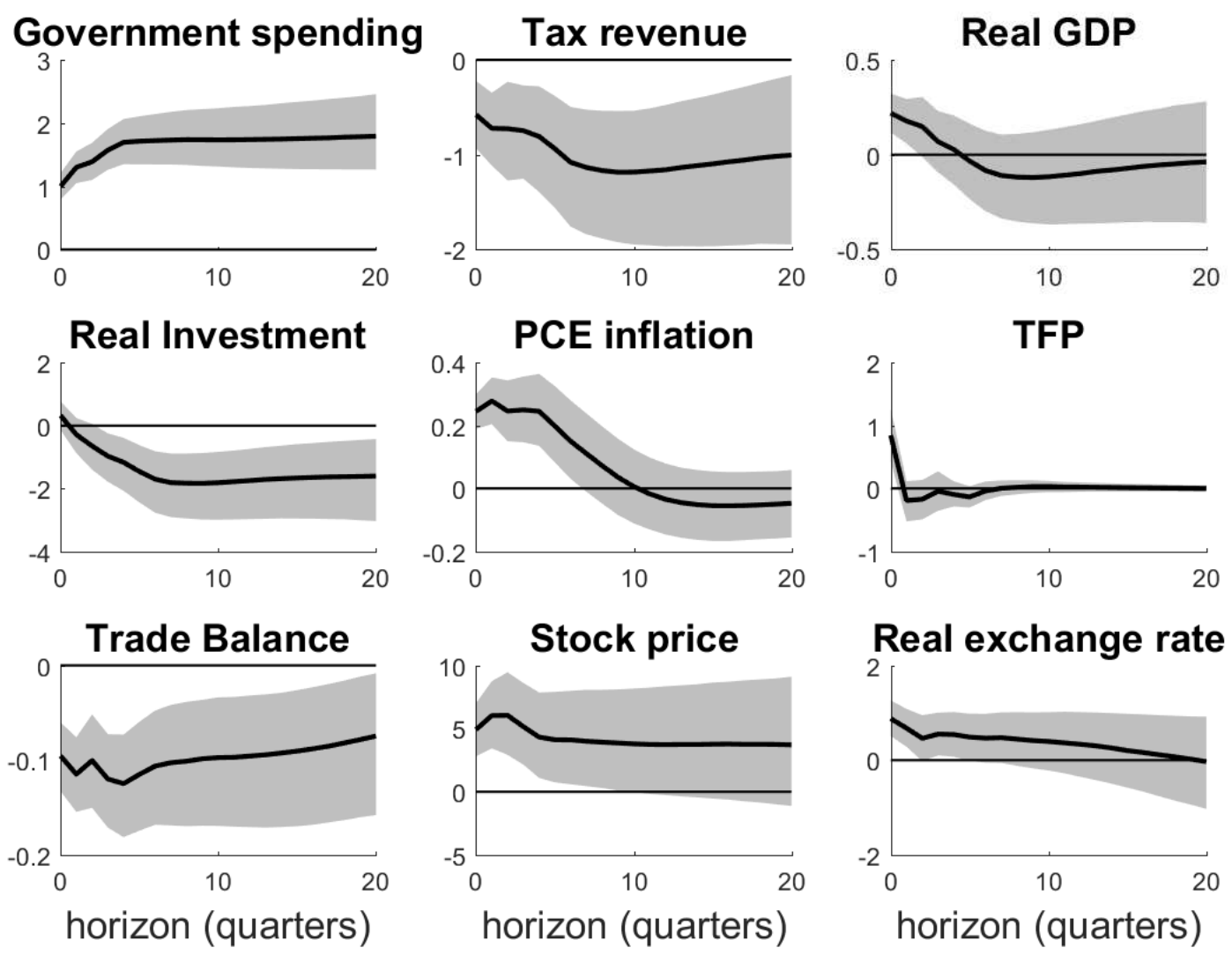

Figure 9: Investment. Impulse responses from a one standard deviation government spending shock including investment. The real effective exchange rate is defined as the weighted basket of foreign goods to domestic goods: an increase stands for an appreciation. The impulse responses are obtained in a proxySVAR framework in which government spending is instrumented with the military narrative series of Ramey (2016a). Shaded bands denote the $68 \%$ pointwise credible sets. 


\section{References}

Altig, D., Christiano, L.J., Eichenbaum, M., Lindé, J., 2011. Firm-specific capital, nominal rigidities and the business cycle. Review of Economic Dynamics 14, 225 - 247.

Auerbach, A.J., Gorodnichenko, Y., 2013. Output Spillovers from Fiscal Policy. American Economic Review 103, 141-146.

Auerbach, A.J., Gorodnichenko, Y., 2016. Effects of Fiscal Shocks in a Globalized World. IMF Economic Review 64, 177-215.

Basu, S., S. Kimball, M., 2003. Investment planning costs and the effects of fiscal and monetary policy. mimeo .

Baxter, M., King, R.G., 1993. Fiscal Policy in General Equilibrium. American Economic Review 83, 315-334.

Blanchard, O., Perotti, R., 2002. An Empirical Characterization of the Dynamic Effects of Changes in Government Spending and Taxes on Output. The Quarterly Journal of Economics 117, 1329-1368.

Boehm, C.E., 2019. Government consumption and investment: Does the composition of purchases affect the multiplier? Journal of Monetary Economics .

Born, B., D'Ascanio, F., Müller, G.J., Pfeifer, J., 2019. The worst of both worlds: Fiscal policy and fixed exchange rates. CEPR working Paper DP14073. Centre for Economic Policy Research.

Born, B., Juessen, F., Müller, G.J., 2013. Exchange rate regimes and fiscal multipliers. Journal of Economic Dynamics and Control 37, 446-465.

Caldara, D., Kamps, C., 2017. The Analytics of SVARs: A Unified Framework to Measure Fiscal Multipliers. Review of Economic Studies 84, 1015-1040.

Canova, F., Pappa, E., 2007. Price Differentials in Monetary Unions: The Role of Fiscal Shocks. Economic Journal 117, 713-737.

Canova, F., Sahneh, M.H., 2018. Are Small-Scale SVARs Useful for Business Cycle Analysis? Revisiting Nonfundamentalness. Journal of the European Economic Association 16, 1069-1093. 
Canzoneri, M.B., Cumby, R.E., Diba, B.T., 2002. Should the European Central Bank and the Federal Reserve be concerned about fiscal policy? Proceedings - Economic Policy Symposium - Jackson Hole , 333-389.

Corsetti, G., Dedola, L., Leduc, S., 2008. International risk sharing and the transmission of productivity shocks. Review of Economic Studies 75, 443-473.

Corsetti, G., Kuester, K., Muller, G.J., 2011. Floats, pegs and the transmission of fiscal policy. Working Papers 11-9. Federal Reserve Bank of Philadelphia.

Corsetti, G., Meier, A., Muller, G., 2009. Cross-border spillovers from fiscal stimulus. CEPR Discussion Papers 7535. C.E.P.R. Discussion Papers.

Corsetti, G., Muller, G.J., 2013. Multilateral Economic Cooperation and the International Transmission of Fiscal Policy, in: Globalization in an Age of Crisis: Multilateral Economic Cooperation in the Twenty-First Century. National Bureau of Economic Research, Inc. NBER Chapters, pp. 257-297.

D'Alessandro, A., Fella, G., Melosi, L., 2019. Fiscal Stimulus With Learning by Doing. International Economic Review 60, 1413-1432.

Del Negro, M., Schorfheide, F., 2011. Bayesian Macroeconometrics. Handbook of Bayesian Econometrics Geweke .

Dupor, B., Li, R., 2015. The expected inflation channel of government spending in the postwar U.S. European Economic Review 74, 36-56.

Edelberg, W., Eichenbaum, M., Fisher, J.D., 1999. Understanding the Effects of a Shock to Government Purchases. Review of Economic Dynamics 2, 166-206.

Enders, Z., Muller, G.J., Scholl, A., 2011. How do fiscal and technology shocks affect real exchange rates?: New evidence for the United States. Journal of International Economics 83, 53-69.

Faccini, R., Mumtaz, H., Surico, P., 2016. International fiscal spillovers. Journal of International Economics 99, 31-45.

Fatás, A., Mihov, I., 2001a. Fiscal policy and business cycles: An empirical investigation. Moneda Y Credito 212, 167-210.

Fatás, A., Mihov, I., 2001b. The Effects of Fiscal Policy on Consumption and Employment: Theory and Evidence. CEPR Discussion Papers 2760. C.E.P.R. Discussion Papers. 
Fernald, J., 2012. A quarterly, utilization-adjusted series on total factor productivity. Federal Reserve Bank of San Francisco Working Paper Series 09.

Forni, M., Gambetti, L., 2014. Sufficient information in structural VARs. Journal of Monetary Economics 66, 124-136.

Forni, M., Gambetti, L., 2016. Government spending shocks in open economy VARs. Journal of International Economics 99, 68-84.

Galí, J., López-Salido, J.D., Vallés, J., 2007. Understanding the Effects of Government Spending on Consumption. Journal of the European Economic Association 5, 227-270.

Galí, J., Monacelli, T., 2005. Monetary policy and exchange rate volatility in a small open economy. Review of Economic Studies 72, 707-734.

Ilzetzki, E., Jin, K., 2013. The Puzzling Change in the International Transmission of US Macroeconomic Policy Shocks. working Paper. mimeo.

Ilzetzki, E., Mendoza, E.G., Vegh, C.A., 2013. How big (small?) are fiscal multipliers? Journal of Monetary Economics 60, 239-254.

Ilzetzki, E., Reinhart, C.M., Rogoff, K.S., 2017. The Country Chronologies to Exchange Rate Arrangements into the 21st Century: Will the Anchor Currency Hold? NBER Working Papers 23135. National Bureau of Economic Research, Inc.

Jaimovich, N., Rebelo, S., 2009. Can news about the future drive the business cycle? American Economic Review 99, 1097-1118.

Jorgensen, P., Ravn, S., 2019. The Inflation Response to Government Spending Shocks: A Fiscal Price Puzzle? .

Kim, S., 2015. Country characteristics and the effects of government consumption shocks on the current account and real exchange rate. Journal of International Economics 97, $436-447$.

Kim, S., Roubini, N., 2008. Twin deficit or twin divergence? Fiscal policy, current account, and real exchange rate in the U.S. Journal of International Economics 74, 362-383.

Kim, S.H., Moon, S., Velasco, C., 2017. Delayed overshooting: Is it an 80s puzzle? Journal of Political Economy 125, 1570-1598.

Lambertini, L., Proebsting, C., 2019. Fiscal Policy, Relative Prices and Net Exports in a Currency Union. working Paper. mimeo. 
Linnemann, L., 2006. The Effect of Government Spending on Private Consumption: A Puzzle? Journal of Money, Credit and Banking 38, 1715-1735.

Lunsford, K.G., 2016. Identifying Structural VARs with a Proxy Variable and a Test for a Weak Proxy. Working Papers (Old Series) 1528. Federal Reserve Bank of Cleveland.

McCracken, M.W., Ng, S., 2016. FRED-MD: A Monthly Database for Macroeconomic Research. Journal of Business \& Economic Statistics 34, 574-589.

Mendoza, E.G., 1991. Real business cycles in a small open economy. American Economic Review 81,797-818.

Mertens, K., Ravn, M.O., 2013. The dynamic effects of personal and corporate income tax changes in the united states. American Economic Review 103(4), 1212-1247.

Miyamoto, W., Nguyen, T.L., Sheremirov, V., 2019. The effects of government spending on real exchange rates: Evidence from military spending panel data. Journal of International Economics 116, $144-157$.

Monacelli, T., Perotti, R., 2008. Openness and the Sectoral Effects of Fiscal Policy. Journal of the European Economic Association 6, 395-403.

Monacelli, T., Perotti, R., 2010. Fiscal Policy, the Real Exchange Rate and Traded Goods. Economic Journal 120, 437-461.

Montiel Olea, J.L., Pflueger, C., 2013. A robust test for weak instruments. Journal of Business \& Economic Statistics 31, 358-369.

Montiel Olea, J.L., Stock, J.H., Watson, M.W., 2018. Inference in structural vector autoregressions identified with an external instrument. mimeo .

Mountford, A., Uhlig, H., 2009. What are the effects of fiscal policy shocks? Journal of Applied Econometrics 24, 960-992.

Mussa, M., 1986. Nominal exchange rate regimes and the behavior of real exchange rates: Evidence and implications. Carnegie-Rochester Conference Series on Public Policy 25, $117-214$.

Nakamura, E., Steinsson, J., 2014. Fiscal Stimulus in a Monetary Union: Evidence from US Regions. American Economic Review 104, 753-792.

Perotti, R., 2005. Estimating the effects of fiscal policy in OECD countries. Proceedings . 
Ramey, V.A., 2011. Identifying Government Spending Shocks: It's all in the Timing. The Quarterly Journal of Economics 126, 1-50.

Ramey, V.A., 2016a. Defense news shocks, 1889-2015: Estimates based on news sources. Unpublished manuscript .

Ramey, V.A., 2016b. Macroeconomic Shocks and Their Propagation. NBER Working Papers 21978. National Bureau of Economic Research, Inc.

Ramey, V.A., Zubairy, S., 2018. Government spending multipliers in good times and in bad: Evidence from us historical data. Journal of Political Economy 126, 850-901.

Ravn, M., Schmitt-Grohé, S., Uribe, M., 2006. Deep Habits. Review of Economic Studies 73, 195-218.

Ravn, M.O., Schmitt-Grohe, S., Uribe, M., 2012. Consumption, government spending, and the real exchange rate. Journal of Monetary Economics 59, 215-234.

Ricco, G., Callegari, G., Cimadomo, J., 2016. Signals from the government: Policy disagreement and the transmission of fiscal shocks. Journal of Monetary Economics 82, $107-118$.

Romer, C.D., Romer, D.H., 2010. The Macroeconomic Effects of Tax Changes: Estimates Based on a New Measure of Fiscal Shocks. American Economic Review 100, 763-801.

Schmitt-Grohé, S., Uribe, M., 2003. Closing small open economy models. Journal of International Economics 61, 163-185.

Schmitt-Grohé, S., Uribe, M., 2017. Open Economy Macroeconomics. Princeton Press.

Stock, J.H., Watson, M.W., 2008. Lecture 7: Recent Developments in Structural VAR Modeling. Presented at the National Bureau of Economic Research Summer Institute Minicourse: What's New in Econometrics: Time Series, Cambridge, MA .

Stock, J.H., Watson, M.W., 2018. Identification and estimation of dynamic causal effects in macroeconomics using external instruments. The Economic Journal 128, 917-948.

Zeev, N.B., Pappa, E., 2017. Chronicle of a War Foretold: The Macroeconomic Effects of Anticipated Defence Spending Shocks. Economic Journal 127, 1568-1597. 